\title{
GEDUNG MERDEKA SEBAGAI OBJEK WISATA DI KOTA BANDUNG
}

\author{
MERDEKA BUILDING AS A TOURISM OBJECT IN BANDUNG
}

\author{
Nandang Firman Nurgiansyah \& Miftahul Falah \\ Fakultas Ilmu Budaya (FIB) Universitas Padjadjaran \\ Jl. Raya Bandung Sumedang Km. 21, Jatinangor 45363 \\ e-mail: nandangfirman@gmail.com
}

\begin{abstract}
Abstrak
Penelitian ini bertujuan untuk menjelaskan upaya yang diperlukan bagi pengembangan fungsi Gedung Merdeka sebagai objek wisata. Penelitian ini menggunakan metode sejarah, yang terdiri dari tahapan heuristik, kritik, interpretasi, dan historiografi. Berdasarkan hasil penelitian, Gedung Merdeka belum dimanfaatkan secara optimal sebagai daya tarik wisata dan kurangnya fasilitas wisata di gedung tersebut. Gedung Merdeka memiliki daya tarik sebagai benda cagar budaya yang bernilai historis dan terdapat Museum KAA di salah satu bagian gedungnya. Museum tersebut mengoleksi dan memamerkan benda dan foto yang berkaitan dengan Konferensi Asia Afrika. Selain itu, sarana wisata yang perlu ditambah seperti cafetaria, coffee shop, tempat duduk dan bersantai untuk wisatawan dan ruangan audio visual yang lebih menarik. Oleh sebab itu, perlu optimalisasi fungsi komplek Gedung Merdeka sebagai daya tarik wisata.
\end{abstract}

Kata Kunci: Gedung Merdeka, pengembangan, dan pariwisata

\begin{abstract}
The thesis It aims to explain the efforts need for the development function of Gedung Merdeka as tourist attraction. The thesis uses the history research methods, which of heuristic, critic, interpretation, and historiography. Based on theresearch results, problems encountered the building that is not used optimally as a tourist attraction, the lack of tourist facilities in the building. Gedung Merdeka has an attraction as a cultural heritage object of historical value and there is KAA Museum in one part of the building. The museum collects and exhibits objects and photos related to the Asian African Conference. In addition, tourist facilities that need to be added such as cafeteria, coffee shop, seating and relax for tourists and audio visual space more attractive. Therefore, it needs to optimize complex functions the Gedung Merdeka as a tourist attraction.
\end{abstract}

Keywords: Merdeka Buildings, development, and tourism.

\section{A. PENDAHULUAN}

Kota Bandung dikenal sebagai pusat pendidikan dan pemerintahan. Pada masa kolonial di kota ini berdiri lembaga pendidikan. Oleh sebab itu, Kota Bandung menjadi salah satu tujuan orang tua dari berbagai daerah untuk menyekolahkan anak mereka. Bandung juga dikenal sebagai ibu kota Provinsi Jawa Barat. Konsekuensi sebagai ibu kota provinsi, maka dibangun fasilitas umum yang lebih lengkap. Kota ini dikenal juga sebagai daerah tujuan wisata. Udaranya yang sejuk dan fasilitas hiburan yang lengkap menjadi 
daya tarik wisatawan dari berbagai daerah untuk berkunjung. Selain itu, di kota ini banyak berdiri pasar modern yang membuat keberadaannya semakin ramai dikunjungi oleh wisatawan.

Salah satu peristiwa penting yang terjadi Kota Bandung yaitu Konferensi Asia Afrika (KAA) yang berlangsung di Gedung Merdeka pada 1955. Tokoh penting dari Indonesia, Ir. Soekarno menyampaikan pidato pembukaan yang memukau pemimpin bangsa-bangsa Asia dan Afrika. Dengan berlangsungnya Konferensi Asia Afrika di Bandung maka kota ini dikenal juga sebagai ibu kota Asia Afrika. Selain itu, gedung yang menjadi saksi peristiwa bersejarah Konferensi Asia Afrika dapat dinikmati hingga saat ini. Konferensi yang menghasilkan Dasa Sila Bandung telah membawa negara-negara di Asia dan Afrika untuk menjadi sebuah bangsa yang dapat menciptakan perdamaian dunia. Setelah konferensi tersebut, gedung ini pun sering digunakan konferensi lain yang bertaraf nasional dan internasional. Sebab itu, sudah seharusnya Gedung Merdeka dan peristiwa bersejarah yang berhubungan dengannya diketahui oleh masyarakat luas.

Adanya Gedung Merdeka yang memiliki nilai sejarah dan masih berdiri sampai saat ini dapat ditawarkan ke masyarakat untuk menjadi objek wisata. Setiap akhir pekan pun banyak wisatawan yang berkunjung ke Kota Bandung. Hal ini dapat dimanfaatkan untuk menarik wisatawan dari berbagai daerah untuk mengunjungi Gedung Merdeka. Selain dapat dikembangkan untuk kepentingan wisata, juga tidak kalah penting sebagai sarana pendidikan terhadap masyarakat mengenai peran diplomasi Bangsa Indonesia untuk dunia. Selain itu, untuk mengenalkan sejarah Konferensi Asia Afrika dengan cara melihat peninggalannya yang ada di Museum KAA. Namun demikian, Gedung Merdeka sebagai aset bangsa yang memiliki nilai sejarah belum dimanfaatkan secara optimal. Baru sayap kiri gedung yang telah dimanfaatkan sebagai museum dan ruang utama (main hall) yang dapat dikunjungi oleh wisatawan. Akan tetapi, ruangan-ruangan lain belum dapat dikunjungi oleh masyarakat, padahal bila semua ruangan dan bangunan yang berada di komplek Gedung Merdeka dapat dijadikan objek wisata maka akan menambah daya tarik untuk dikunjungi. Selain itu, masyarakat umum belum banyak mengetahui tentang latar belakang pendirian Gedung Merdeka, serta nilai historis yang ada pada gedung tersebut. Masalah utama dalam penelitian ini adalah Bagaimana upaya yang diperlukan untuk pengembangan fungsi Gedung Merdeka sebagai objek wisata? Sedangkan tujuan penelitian ini yaitu untuk menjelaskan upaya yang diperlukan bagi pengembangan fungsi Gedung Merdeka sebagai objek wisata.

Buku yang menjadi tinjauan penulis untuk menyelesaikan penelitian ini, antara lain, Braga; Jantung Parijs Van Java (2008) karya Ridwan Hutagalung dan Taufanny Nugraha. Buku yang diterbitkan oleh Ka Bandung ini menceritakan tentang Jalan Braga pada awal abad ke-20. Dalam buku ini diceritakan sejarah dan fungsi bangunan yang berjejer di sekitar Jalan Braga. Dalam karya ini juga di bahas tentang sejarah Societeit Concordia beserta kegiatan yang berlangsung di gedung ini. Dalam karya ini, dapat diketahui tentang fungsi Gedung Merdeka pada awal abad ke-20 yang membuatnya menjadi salah satu gedung paling ramai akan kegiatannya.

Buku kedua adalah Panduan Museum Konferensi Asia Afrika (2004) karya Edi S. Ekadjati. Buku ini diterbitkan oleh Departemen Luar Negeri RI. Dalam buku ini dijelaskan tentang sejarah Museum Konferensi Asia Afrika, sejarah Gedung Merdeka, dan sejarah singkat Konferensi Asia Afrika. Buku ini dilengkapi juga dengan daftar nama dan foto ketua delegasi negara peserta Konferensi Asia Afrika, foto Presiden Soekarno beserta rombongan menuju Gedung Merdeka, dan denah Museum 
Konferensi Asia Afrika serta denah Gedung Merdeka. Dari karya ini, dapat diketahui tentang gambaran umum Gedung Merdeka dan Museum KAA.

Buku ketiga adalah Sejarah Konferensi Asia Afrika yang terbit pada 2011. Buku ini merupakan hasil karya dari panitia penulisan sejarah diplomasi Republik Indonesia. Buku tersebut diterbitkan oleh MKAA, Dirjen Diplik Kementerian Luar Negeri RI. Sebagaimana judulnya, buku ini menguraikan tentang sejarah Konferensi Asia Afrika. Dalam buku tersebut dijelaskan mengenai konferensi sebelum KAA seperti Konferensi Kolombo dan Konferensi Bogor. Setelah pemaparan kedua konferensi tersebut, selanjutnya diuraikan mengenai pelaksaan Konferensi Asia Afrika. Dalam buku ini dilampirkan juga pidato pembukaan Presiden Soekarno yang berjudul "Let a New Asia and a New Afrika Be Born" dan "Final Communique of the Asia Afrika Conference". Buku ini bermanfaat untuk mengetahui tentang sejarah Konferensi Asia Afrika yang didukung oleh foto saat konferensi berlangsung.

Buku berikutnya adalah The Bandung Connection; Konferensi Asia Afrika di Bandung tahun 1955 yang terbit pada 2011. Buku ini merupakan karya dari Roeslan Abdulgani dan diterbitkan oleh MKAA, Dirjen Diplik Kementerian Luar Negeri RI. Buku tersebut menceritakan sejarah Asia Afrika. Dalam buku ini juga dijelaskan mengenai latar belakang sejarah KAA, situasi internasional menjelanag KAA, dan suka duka menjelang pembukaan konferensi. Selain itu diceritakan pula mengenai pidato para ketua delegasi dalam sidang pleno terbuka. Dalam buku ini juga dibahas seputar aktivitas di luar konferensi dan detik-detik penutupan konferensi. Buku ini sangat bermanfaat untuk mengetahui peristiwa KAA dari sudut pandang saksi sejarah KAA. Penulis buku ini terlibat langsung pada saat KAA 1955.
Buku berikutnya adalah Perubahan Sosial di Bandung 1810-1906 yang ditulis oleh A. Sobana Hardjasaputra. Buku ini berupa disertasi yang terbit 2002 di Program Pascasarjana Fakultas Sastra Universitas Indonesia di Depok. Buku ini membahas tentang perubahan sosial di Bandung. Di dalamnya diuraikan apa saja yang menyebabkan Bandung menjadi sebuah kota yang berkembang menuju kota modern. Buku ini sangat membantu untuk mengetahui sejarah dan perkembangan Kota Bandung pada awal abad ke-20 serta kegiatan pariwisata pada masa kolonial.

\section{B. METODE PENELITIAN}

Penelitian ini dilakukan dengan menggunakan metode sejarah. Metode sejarah terdiri dari tahapan heuristik, kritik, interpretasi, dan historiografi (Herlina, 2008: 15-16). Pada penelitian ini, penulis melakukan teknik pengumpulkan data sebagai berikut:

\section{Studi Pustaka}

Studi pustaka dilakukan untuk memperoleh data dan informasi yang berkaitan dengan Gedung Merdeka, Museum KAA, dan pengembangan objek wisata. Studi pustaka yang dilakukan penulis yaitu mengunjungi perpustakaan, museum, kantor arsip Pikiran Rakyat, dan BPS Provinsi Jawa Barat untuk memperoleh sumber-sumber tertulis seperti buku, surat kabar, hasil-hasil penelitian, dan sebagainya. Perpustakaan yang telah dikunjungi yaitu Perpustakaan Museum KAA, Perpustakaan Museum Sri Baduga, Perpustakaan UPI, Perpustakaan ITB, Perpustakaan Fakultas Ilmu Budaya (FIB) Universitas Padjadjaran, Perpustakaan Batu Api Jatinangor, dan Perpustakaan Daerah Jawa Barat.

\section{Observasi}

Observasi yang dilakukan oleh penulis dengan cara pengamatan dan mengunjungi komplek Gedung Merdeka dan Museum KAA di Kota Bandung. Dengan melakukan observasi, penulis 
berusaha untuk mengetahui secara langsung kondisi Gedung Merdeka dan mengamati potensi yang dimilikinya untuk dikembangkan sebagai objek wisata budaya serta sarana pariwisata yang belum tersedia. Pada tahap ini penulis melakukan dokumentasi terhadap gambar bangunan dan fasilitas yang ada serta koleksi Museum KAA. Teknik dokumentasi dilakukan dengan cara pengambilan foto dengan memakai media kamera digital.

\section{Wawancara}

Wawancara merupakan teknik pengumpulan data yang dilakukan dengan mengadakan komunikasi kepada orang yang berada di Gedung Merdeka dan orang yang dianggap mempunyai pengetahuan tentang topik penelitian. Pada tahap ini penulis melakukan wawancara dengan staf Museum KAA, staf Badan Pengelola Gedung Merdeka, dan wisatawan yang berkunjung ke Museum KAA. Selain itu, dalam penelitian ini digunakan pendekatan pariwisata.

Dalam pengembangan suatu daerah menjadi tujuan wisata maka harus memenuhi tiga syarat, yaitu:

a. Something to see, artinya di tempat tersebut ada yang dapat dilihat dan disaksikan.

b. Something to do, artinya di tempat tersebut ada yang dapat dilakukan.

c. Something to buy, artinya di tempat tersebut harus tersedia fasilitas untuk berbelanja (Shopping), terutama barang-barang souvenir dan kerajinan daerah sebagai oleh-oleh (Yoeti, 1996: 178).

Selain ketiga syarat itu yang perlu dipenuhi untuk pengembangan sebuah objek wisata juga perlu diperhatikan product style agar dapat memuaskan wisatawan. Product style tersebut seperti adanya:

1. Objek wisata yang harus menarik untuk disaksikan maupun dipelajari.

2. Mempunyai kekhususan dan berbeda dari objek yang lain.
3. Prasarana menuju ke tempat wisata terpelihara dan baik.

4. Tersedia fasilitas something to see, something to do, dan something to buy.

5. Sarana-sarana akomodasi dan hal lain yang dianggap perlu untuk kepentingan wisatawan (Yoeti, 1996: 159).

Pemasaran wisata perlu dilakukan agar sebuah objek wisata dapat diketahui dan dikunjungi oleh wisatawan. Pemasaran pariwisata meliputi sejumlah kegiatan yang dimaksudkan untuk memengaruhi, menghimbau, dan merayu wisatawan potensial sebagai konsumen agar mengambil keputusan untuk mengadakan perjalanan wisata (Soekadijo dalam Rakhman, 2011: 12). Dalam pengembangkan pariwisata perlu dilakukan suatu promosi. Promosi ini meliputi beberapa aspek, yaitu:

1. Menarik perhatian wisatawan.

2. Membangun suatu perjalanan dengan keuntungan yang ditawarkan.

3. Menciptakan sikap positif tentang apa yang telah dipromosikan.

4. Membangun tempat-tempat untuk pilihan wisatawan.

5. Mendapatkan atau mencari wisatawan untuk berkunjung.

6. Meyakinkan wisatawan untuk kembali lain waktu (Marpaung dalam Rakhman, 2011: 12).

\section{HASIL DAN BAHASAN \\ 1. Proses Pendirian Gedung Merdeka}

Gedung Merdeka berlokasi di Jalan Asia Afrika No. 65. Arsitek yang merancang gedung tersebut bernama Van Gallen Last dan C. P. Wolff Schoemaker, sedangkan ruangan yang sekarang dipakai oleh Museum Konferensi Asia Afrika sempat dirombak pada tahun 1940. Arsitek yang merancang ruangan tersebut ialah Ir. A.F. Aalbers (Hutagalung dan Nugraha, 2008: 34-36) 


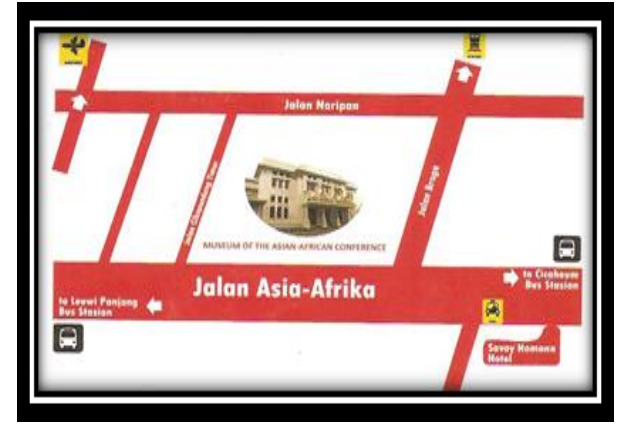

Gambar 1. Peta Lokasi Gedung Merdeka dan Museum KAA

Sumber: Koleksi Museum KAA

Pada 1895 belum dikenal nama Gedung Merdeka. Pada masa itu, gedung tersebut bernama Gedung Societeit Concordia. Gedung ini digunakan sebagai tempat rekreasi dan hiburan orang-orang Belanda. Kelompok Belanda yang sering berkumpul di gedung ini berasal dari kalangan pengusaha perkebunan, perwira, pembesar, dan kalangan lainnya yang cukup kaya dan mempunyai kedudukan (Ekadjati, 2004: 10).

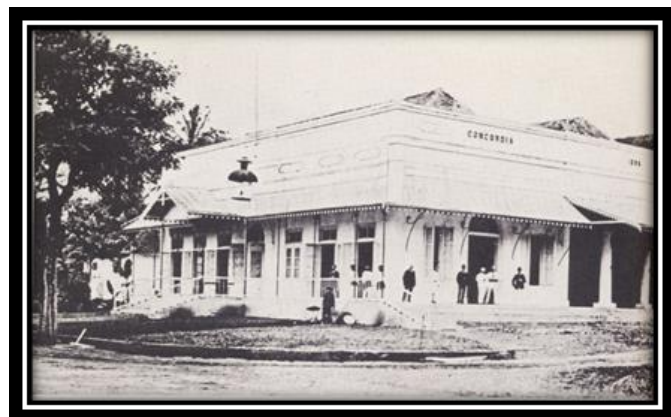

Gambar 2. Gedung Concordia pada1895 Sumber: (Buitenweg, 1976: 46)

Aktivitas di gedung ini selalu ramai dengan berbagai macam kegiatan dan hiburan. Biasanya pada hari libur dijadikan ajang berkumpul dan rekreasi anggota perkumpulan Societeit Concordia. Puncak acara dan kegiatan tersebut berlangsung pada malam hari. Di dalam gedung ini diadakan pertunjukan kesenian, makan malam, dan hiburan menarik (Ekadjati, 2004: 10).

Di dalam Gedung Concordia terdapat ruangan yang dapat menampung berbagai macam kegiatan hiburan. Oleh sebab itu, ruangan tersebut sering dipakai dan disewa oleh salah satu kelompok perkumpulan kesenian yang ada di Kota Bandung. Kelompok tersebut bernama Persatuan Sandiwara Braga. Kelompok Persatuan ini belum memiliki gedung pertunjukan sendiri sehingga sering menyewa ruangan di Gedung Concordia untuk konser seni (Ekadjati, 2004: 10). Di gedung ini sering diadakan pertunjukan konser musik dan dansa pada setiap akhir pekan. Selain itu, diselenggarakan suatu pertunjukan di halaman gedung yang terbuka untuk umum.

Kegiatan di Gedung Societeit Concordia biasanya terpusat pada saat pengusaha perkebunan liburan. Mulai Sabtu pagi anggota Societeit Concordia sudah berkumpul di Gedung Concordia untuk menikmati sajian orkes musik. Pada malam Minggu digunakan untuk pesta dansa. Mulai Minggu saatnya remaja Belanda yang meramaikan gedung Societeit Concordia. Para pemuda Belanda bermain sepatu roda di ruang utama gedung tersebut (Hutagalung dan Nugraha, 2008: 39).

Di Gedung Concordia difasilitasi juga dengan ruang makan, ruang dansa yang luas, ruang bola sodok, ruang bola gelinding, serta perpustakaan yang tergolong besar dan lengkap. Teras depan gedung ini memiliki daya tarik sendiri untuk bersantai sambil melihat keramaian kota (Hutagalung dan Nugraha, 2008: 42).

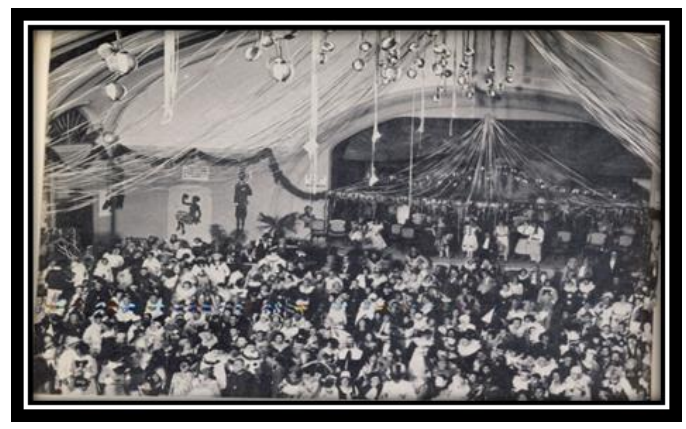

Gambar 3. Suasana Pesta di Ruang Utama (Main Hall) Gedung Concordia pada 1920 Sumber: (Buitenweg, 1976: 50) 


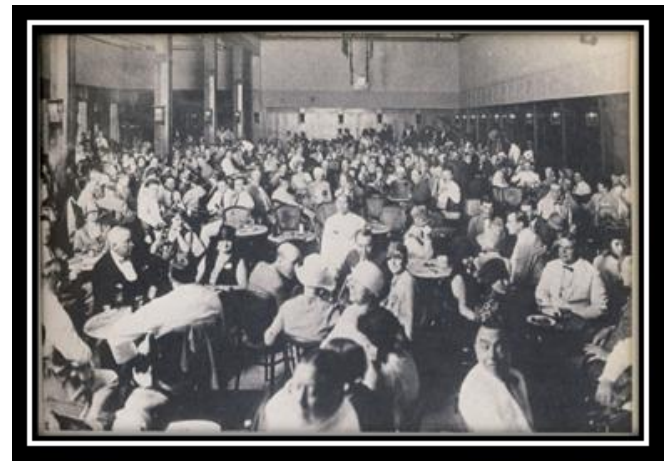

Gambar 4. Suasana Pesta dan Makan di Lobi

Baru Gedung Concordia pada 1928

Sumber: (Buitenweg, 1976: 49)

Perkumpulan Societeit Concordia juga sering mengadakan acara hiburan spesial. Acara khusus tersebut bernama Bragabal. Acara ini diselenggarakan dalam jangka waktu tiga bulan sekali dalam setahun. Acara ini ramai dengan kegiatan pesta musik dan pesta dansa. Dalam pesta ini berbagai kelompok musik memakai pakaian yang warna-warni dan menarik perhatian (Hutagalung dan Nugraha, 2008: 40).

Societeit ini juga sering mengadakan acara buat menyambut malam pergantian tahun. Pada saat pesta malam tahun baru juga biasanya dihidangkan makan malam. Restoran yang menyajikan hidangan makan malam ialah dari Hotel Savoy Homann. Hotel ini menyajikan makan malam buat pesta karena letaknya yang dekat dengan Gedung Concordia dan termasuk hotel mewah di zamannya (Hutagalung dan Nugraha, 2008: 40-41).

Kegiatan-kegiatan yang ada di Gedung Concordia mendapatkan dukungan dari berbagai macam komunitas seni Kota Bandung. Komunitas tersebut seperti komunitas seni, perkumpulan musik, perkumpulan tonil, kelompok paduan suara, dan komunitas lainnya. Mulai dari pertunjukan tonil, konser musik, dansa, tari balet, pameran lukisan, dan acara-acara khusus lain seperti perayaan akhir tahun yang diadakan oleh beberapa sekolah terkemuka di Bandung (Hutagalung dan Nugraha, 2008: 57)
Pada saat itu, Gedung perkumpulan ini termasuk yang paling megah dan mewah. Kemewahan Concordia terlihat dari lantai yang terbuat dari marmer buatan Italia. Ruangan tempat makan-minum dan bersantai terbuat dari kayu cikenhout. Penerangannya dipakai lampu hias kristal yang gemerlapan (Ekadjati, 2004: 11).

Pada tahun 1942-1945, Gedung Societeit Concordia dikuasai oleh tentara Pendudukan Jepang. Pada masa ini nama gedung diubah menjadi nama yang berasal dari bahasa Jepang yaitu Dai Toa Kaikan. Gedung ini berfungsi sebagai pusat kebudayaan. Meskipun demikian, kegiatan yang berhubungan dengan kesenian dan hiburan masih tetap berlagsung di gedung ini (Ekadjati, 2004: 11).

Setelah tahun 1945 gedung Concordia menjadi markas pemuda di Kota Bandung untuk menghadapi tentara pendudukan Jepang. Pada saat itu, tentara Jepang belum bersedia menyerahkan kekuasaannya. Akan tetapi, pada saat tentara Sekutu datang ke Kota Bandung, gedung tersebut dijadikan tempat kegiatan pemerintah Kota Bandung. Setelah adanya ultimatum dari pihak Sekutu, gedung tersebut ditinggalkan dari kegiatan pemerintahan (Ekadjati, 2004: 11-13).

Pada tahun 1954 pemerintah Republik Indonesia menetapkan Bandung sebagai tempat Konferensi Asia Afrika. Dengan demikian, dibutuhkan gedung yang besar untuk tempat konferensi. Oleh sebab itu, Gedung Societeit Concordia dipilih dan ditetapkan sebagai tempat konferensi. Selain gedungnya yang megah dan mewah juga karena letaknya yang strategis serta berdekatan dengan hotel terbaik yang ada di Kota Bandung. Hotel tersebut ialah Savoy Homann Bidakara, dan Grand Preanger (Ekadjati, 2004: 1113).

Dengan dijadikannya Gedung Concordia sebagai tempat konferensi maka dilakukan pemugaran. Perbaikan gedung tersebut disesuaikan dengan fungsinya untuk tempat penyelenggaraan konferensi 
tanpa mengubah bentuk aslinya. Pemugarannya ditangani oleh Jawatan Pekerjaan Umum Provinsi Jawa Barat yang dipimpin oleh Ir. R. Srigati Santoso (Ekadjati, 2004: 13).

$$
\text { Sebelum }
$$

berlangsungnya

Konferensi Asia Afrika, Gedung Concordia dan Gedung Dana Pensiun diganti namanya oleh Presiden Soekarno. Gedung Concordia diubah menjadi Gedung Merdeka dan Gedung Dana Pensiun menjadi Gedung Dwi Warna. Pada saat Konferensi Asia Afrika berlangsung, Gedung Merdeka digunakan untuk memenuhi kebutuhan konferensi. Gedung tersebut digunakan untuk upacara pembukaan, sidang pleno, dan upacara penutupan, sedangkan Gedung Dwi Warna digunakan untuk sidang komisi (Ekadjati, 2004: 14).

Semenjak tahun 1955, Gedung Merdeka difungsikan sebagai Gedung Konstituante. Akan tetapi, setelah Konstituante dibubarkan maka gedung tersebut ditempati oleh Badan Perancang Nasional. Lembaga tersebut tidak lama menempati gedung ini karena pada tahun 1960 gedung tersebut menjadi Gedung Majelis Permusyawaratan Rakyat Sementara (MPRS). Kegiatan MPRS mulai tahun 1971 dialihkan ke Jakarta (Ekadjati, 2004: 14).

Pada saat tejadi pemberontakan 30 September, Gedung Merdeka dipakai oleh instansi militer. Sebagai ruang gedung tersebut juga dimanfaatkan sebagai tempat tahanan politik gerakan 30 September. Pada tahun 1966 pemeliharaan gedung ini diserahkan oleh Pemerintah Republik Indonesia kepada Pemerintah Provinsi Jawa Barat. Oleh Pemerintah daerah Jawa Barat, selanjutnya diserahkan pelaksanaannya kepada pemerintah Kotamadya Bandung. Akan tetapi, pada 6 Juli 1968 pimpinan MPRS merevisi surat keputusan Gedung Merdeka. Dengan adanya surat revisi tersebut, maka bangunan yang berada di belakang gedung tersebut tetap di bawah tanggung jawabnya (Ekadjati, 2004: 14).
Pemerintah Provinsi Jawa Barat menunjuk pengelola Gedung Merdeka pada September 1968. Pemerintah provinsi pun mengambil alih pengelolaan Gedung Merdeka dari pemerintah kotamadya pada Maret 1969. Dengan demikian sejak saat itu pengelolaan Gedung Merdeka berada di bawah pemerintah provinsi. Sebagai kepala pengelolanya, maka ditunjuk Ibe Jusuf. Berkaitan dengan adanya perombakan organisasi di pemerintah provinsi, maka ditunjuk seorang manajer untuk mengelola Gedung Merdeka. R. Ipung Gandapraja sebagai manajer dan Ibe Yusuf sebagai asisten manajer (Ekadjati, 2004: 14).

$\begin{array}{llll}\text { Pada } & 24 \quad \text { April } & 1980\end{array}$ diselenggarakan peringatan ke-25 Konferensi Asia Afrika di Gedung Merdeka. Pada puncak acara peringatan diadakan peresmian Museum Konferensi Asia Afrika oleh Presiden Soeharto. Seluruh Gedung Merdeka ditetapkan sebagai lokasi Museum Konferensi Asia Afrika oleh Pemerintah Republik Indonesia (Ekadjati, 2004: 14-15).

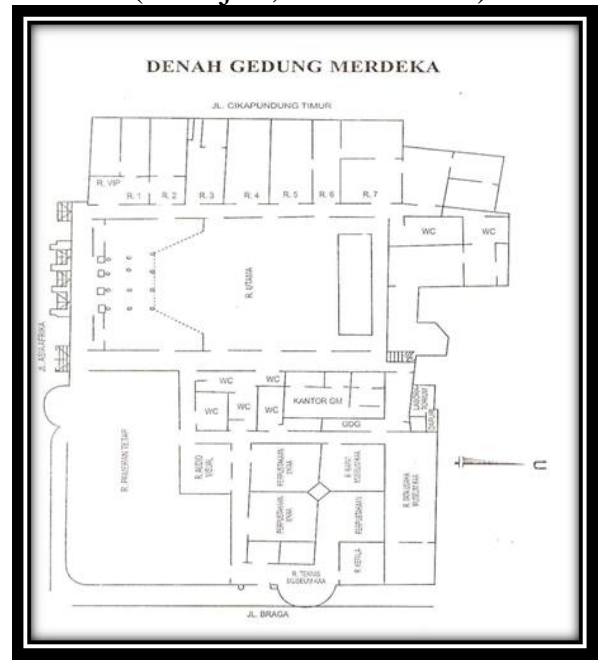

Gambar 5. Denah Gedung Merdeka Sumber: (Departemen Luar Negeri RI, 2011 dan Ekadjati, 2004: 67)

\section{Museum Konferensi Asia Afrika}

Museum Konferensi Asia Afrika lahir dari gagasan Mochtar Kusumaatmadja. Pada saat itu, Mochtar Kusumaatmadja menjabat sebagai Menteri 
Luar Negeri Republik Indonesia. Sebagaimana tugasnya seorang Menteri Luar Negeri, maka ia sering berkunjung ke negara-negara sahabat, termasuk yang ada di Benua Asia dan Afrika. Pada saat ia bertemu dengan para pemimpin negaranegara di dua kawasan tersebut, sering ditanya mengenai keberadaan Gedung Merdeka dan Kota Bandung. Para pemimpin negara di Asia dan Afrika bukan sekedar menanyakan keadaan Gedung Merdeka dan Bandung, tetapi ada keinginan untuk melihat dan mengunjunginya langsung (Ekadjati, 2004: 4).

Atas dasar adanya keinginan dari pemimpin negara di kawasan Asia Afrika untuk melihat kondisi Gedung Merdeka dan Kota Bandung, maka penting untuk menjadikan Gedung Merdeka sebagai sebuah museum. Alasan lain untuk mendirikan museum yakni untuk mengabadikan Konferensi Asia Afrika yang merupakan sebuah prestasi politik luar negeri Republik Indonesia, yang semangat dan pengaruhnya menyebar ke kawasan Asia Afrika. Gagasannya untuk mendirikan sebuah Museum Konferensi Asia Afrika disampaikan pada saat rapat panitia peringatan ke-25 Konferensi Asia Afrika. Dalam rapat tersebut hadir Direktur Jenderal Kebudayaan Haryati Soebadio selaku wakil dari Departemen Pendidikan dan Kebudayaan. Gagasan yang disampaikan Mochtar Kusumaatmadja mendapat sambutan baik, termasuk dari Presiden RI Soeharto. Oleh sebab itu, salah satu aktivitas panitia peringatan ke-25 Konferensi Asia Afrika adalah mendirikan Museum Konferensi Asia Afrika (Ekadjati, 2004: 4).

Pendirian Museum Konferensi Asia Afrika dilaksankan oleh Joop Ave. Pada saat itu ia menjadi Ketua Harian Peringatan Konferensi Asia Afrika dan sebagai Direktur Jenderal Protokol dan Konsuler Departeman Luar Negeri RI. Untuk mewujudkannya itu, maka ia dan panitia peringatan bekerja sama dengan Departemen Penerangan, Departeman
Pendidikan dan Kebudayaan, Pemerintah Provinsi Jawa Barat,dan Universitas Padjadjaran, sedangkan untuk perencanaan dan pelaksanaan teknis dikerjakan oleh PT Decenta dari Kota Bandung (Ekadjati, 2004: 5).

Pada saat puncak peringatan Konferensi Asia Afrika yang ke-25, maka diresmikan berdirinya Museum Konferensi Asia Afrika oleh Presiden Soeharto. Pada 24 April 1980 bukan hanya acara peringatan sebuah konferensi yang bersejarah, tetapi lahir sebuah museum yang akan menjadi bukti akan tonggak bersatunya negara di kawasan Asia dan Afrika. Museum KAA merupakan museum milik Pemerintah Republik Indonesia. Hal ini Sesuai Surat Keputusan Bersama Menteri Luar Negeri Nomor: 144/07/VI/80/01 dan Menteri Pendidikan dan Kebudayaan Nomor: 0185 a/U/1980 pada 25 Juni 1980. Museum KAA berada dalam wilayah Departemen Pendidikan dan Kebudayaan, yang berada di lingkungan Direktorat Jenderal Kebudayaan yang pengelolaannya ditunjang oleh Departemen Luar Negeri dan Pemerintah Provinsi Jawa Barat (Ekadjati, 2004: 4).

Kedudukan Museum KAA dialihkan dari Departemen Pendidikan dan Kebudayaan ke Departemen Luar Negeri pada 18 Juni 1986. Peralihan tersebut berdasarkan surat keputusan bersama Menteri Luar Negeri Nomor: 62/OR/VI/86/01 dan Menteri Pendidikan dan Kebudayaan Nomor: 0419 a/U/1986, yang dikukuhkan dengan keluarnya Surat Keputusan Menteri Luar Negeri nomor: 173/ OT/X/97/01 pada 23 Oktober 1997. Isi surat tersebut tentang organisasi dan tata kerja Museum KAA yang isinya menunjuk museum sebagai unit pelaksana teknis Badan Penelitian dan Pengembangan Masalah Luar Negeri. Dengan adanya perubahan organisasi di tubuh Departemen Luar Negeri pada 2002, kedudukan Museum KAA dialihkan dari Badan Penelitian dan Pengembangan Masalah Luar Negeri ke Direktorat 
Jenderal Informasi, Diplomasi Publik, dan Perjanjian Internasional (Ekadjati, 2004: $6)$.

Pada saat ini Museum Konferensi Asia Afrika berada di lingkungan Kementerian Luar Negeri Republik Indonesia yang pengelolaannya oleh Ditjen Informasi dan Diplomasi Publik yang berada di Direktorat Diplomasi Publik. Pengelola Museum Konferensi Asia Afrika mengusung Visi, Museum Konferensi Asia Afrika sebagai museum bertaraf internasional dengan pengelolaan profesional. Misi Museum KAA, mendorong kerja sama antarbangsa Asia Afrika melalui pilar people to people contact. Meningkatkan pemahaman mengenai diplomasi Indonesia. Media penelitian dan pengkajian Asia Afrika, dan mempromosikan predikat Bandung sebagai ibu kota Asia Afrika (Departemen Luar Negeri RI, 2011).

\section{Fasilitas Museum KAA}

Pada saat diresmikan, Museum KAA memiliki satu ruang pameran tetap yang memamerkan sejumlah barang dan foto peninggalan Konferensi Asia Afrika 1955 dan peringatan ke-25 Konferensi Asia Afrika tahun 1980. Fasilitas Museum KAA bertambah dengan adanya perpustakaan dan ruang audio visual (Ekadjati, 2004: 4). Fasilitas di Museum Konferensi Asia Afrika sebagai berikut:

\subsection{Pameran Tetap}

Museum Konferensi Asia Afrika memiliki ruang pameran tetap yang memamerkan sejumlah koleksi berupa benda tiga dimensi dan foto dokumenter peristiwa Pertemuan Tugu, Konferensi Kolombo, Konferensi Bogor, dan Konferensi Asia Afrika1955. Pada saat mengadakan sambutan terhadap kunjungan Delegasi Konferensi Tingkat Tinggi X Gerakan Non-Blok, pada tahun 1992 dibuatlah diorama yang menggambarkan situasi pembukaan Konferensi Asia Afrika1955. Pada diorama tersebut tampak Presiden RI Soekarno sedang menyampaikan pidato pembukaan dan dibelakangnya duduk Wakil Presiden Moh. Hatta beserta Perdana Menteri U Nu dari Birma, Sir John Kotelawala dari Srilanka, Ali Sastroamidjojo dari Indonesia, Jawaharlal Nehru dari India, dan Mohammed Ali dari Pakistan. Diorama tersebut dalam bentuk patung dan memakai bahan fiberglass dengan ukuran satu berbanding satu (Ekadjati, 2004: 8).

Dalam persiapan Konferensi Tingkat Tinggi Asia Afrika pada 2005 ada perubahan dalam tata pameran di Museum KAA. Penataan Museum KAA dilaksanakan oleh Departemen Luar Negeri RI bekerja sama dengan Sekretariat Negara RI dan Pemerintah Provinsi Jawa Barat. Pelaksanaan teknis penataan museum dikerjakan oleh Vico Design dan Wika Realty (Dokumen Museum KAA). Dalam ruang pameran tetap terdapat foto dan benda peninggalan Konferensi Asia Afrika sebagai berikut ini:

1. Diorama ruang sidang

2. Bola dunia peta negara peserta KAA 1955

3. Foto-foto Gedung Merdeka Zaman dahulu

4. Meja dan kursi yang digunakan KAA 1955

5. Mesin tik semasa KAA

6. Audio visual (televisi plasma)

7. Koleksi prangko

8. Dasa Sila dalam 29 bahasa

9. Pidato pembukaan KAA oleh Presiden Soekarno

10. Koleksi buku

11. Foto suasana dunia sebelum KAA

12. Panel konferensi pendahuluan

13. Panel kedatangan delegasi

14. Panel persiapan di Bandung

15. Panel KAA

16. Panel suasana di luar sidang

17. Panel ulasan pers tentang KAA

18. Panel kejadian dunia semasa KAA

19. Kamera yang digunakan semasa KAA

20. Panel peristiwa Pasca-KAA

21. Panel ulasan pers dan 25 tahun KAA

22. Panel konsepsi KAA

23. Panel ide dan pemikiran tentang KAA

24. Panel foto dan pencetus gagasan KAA 
25. Panel para ketua delegasi

26. Multimedia sejarah KAA, Gedung Merdeka dan Museum KAA

27. Multimedia profil negara peserta KAA

28. Multimedia keadaan Pasca-KAA

29. Ruang Perpustakaan

30. Ruang Audio Visual

31. Ruang Souvenir

\section{Potensi Gedung Merdeka sebagai Objek Wisata \\ 4.1 Atraksi}

Atraksi merupakan daya tarik dari objek wisata suatu daerah yang dapat menarik wisatawan untuk berkunjung ke tempat wisata. Gedung Merdeka memiliki daya tarik sebagai benda cagar budaya yang bernilai historis. Gedung tersebut digunakan sebagai tempat Konferensi Asia Afrika 1955. Selain itu bangunan gedung mencerminkan gaya art deco dan mempunyai nilai penting bagi sejarah, ilmu pengetahuan, dan kebudayaan. Pada salah satu bagian Gedung Merdeka telah digunakan sebagai museum. Museum tersebut mengoleksi dan memamerkan benda dan foto yang berkaitan dengan Konferensi Asia Afrika. Dengan demikian, Gedung Merdeka memiliki daya tarik wisata yang dapat menarik wisatawan.

\subsection{Aksesibilitas}

Aksesbilitas adalah sarana yang memberikan kemudahan kepada wisatawan untuk mencapai daerah tujuan wisata. Letak Gedung Merdeka yang berada di pusat kota memudahkan wisatawan untuk berkunjung. Selain itu, posisi Gedung Merdeka yang berada di Jalan Asia Afrika mudah dijangkau dari terminal bus, stasiun kereta api, dan bandara. Jarak dari Gedung Merdeka ke Terminal Bus Leuwi Panjang yaitu sekitar dua kilometer, dengan Stasiun Kereta Api Kota Bandung berjarak sekitar satu setengah kilometer, dengan Bandara Husein Sastranegara berjarak sekitar tiga kilometer. Dengan demikian wisatawan dapat mudah menjangkau Gedung Merdeka dan Museum KAA dari jalur manapun. Kendaraan umum (Bus Damri) pun melewati depan gedung ini sehingga dapat memudahkan bagi wisatawan yang berkunjung secara perorangan.

\subsection{Amenitas}

Amenitas adalah fasilitas pendukung demi kelancaran kegiatan yang juga ditunjukkan untuk memberikan kenyamanan kepada wisatawan. Di sekitar Gedung Merdeka terdapat hotel, restoran, kafe, bank, dan apotek. Hotel yang berdekatan dengan Gedung Merdeka diantaranya Hotel Savoy Homann Bidakara dan Hotel Grand Preanger. Hotel ini termasuk salah satu hotel mewah yang ada di Kota Bandung. Selain itu hotel ini juga dibangun pada masa kolonial sehingga memiliki corak yang khas. Di samping itu, hotel Savoy Homann dan Grand Preanger juga memiliki keterkaitan dengan peristiwa Konferensi Asia Afrika. Dengan demikian hotel ini dan Gedung Merdeka memiliki nilai sejarah tersendiri dan memiliki hubungan historis dengan penyelengaraan Konferensi Asia Afrika. Oleh sebab itu, antara pihak hotel dan Gedung Merdeka dapat menjalin kerja sama untuk menarik minat wisatawan. Gedung Merdeka pun berada di kawasan Jalan Braga. Di kawasan ini terdapat restoran, kafe, bank, perusahaan tour and travel, toko lukisan, toko cinderamata, toko kamera, toko buku, dan apotek, yang semuanya itu dapat mendukung kegiatan wisata.

\section{Gedung Merdeka sebagai Destinasi Wisata}

Pengembangan suatu daerah sebagai destinasi harus memenuhi tiga syarat, yaitu:

a. Something to see, artinya di tempat tersebut ada yang dapat dilihat dan disaksikan.

b. Something to do, artinya di tempat tersebut ada yang dapat dilakukan. Selain itu, harus ada fasilitas rekreasi yang dapat membuat wisatawan tinggal lebih lama. 
c. Something to buy, artinya di tempat tersebut harus tersedia fasilitas untuk berbelanja (shopping), terutama barang-barang souvenir dan kerajinan daerah sebagai oleh-oleh (Yoeti, 1996: 178).

Oleh sebab itu, dalam pengembangan Gedung Merdeka sebagai destinasi harus memenuhi syarat "something to see" yaitu adanya koleksi Museum KAA melalui penataan pameran dan penataan ruangan di Gedung Merdeka, "something to do" berupa aktifitas atau kegiatan yang dilakukan wisatawan ketika mengunjungi Gedung Merdeka. Dalam hal ini dibutuhkan inovasi dan kreatifitas dari pihak pengelola dalam memandu wisatawan dan juga membuat programprogram yang dapat melibatkan pengunjung secara aktif. Syarat berikutnya yaitu "something to buy" dengan menyediakan fasilitas untuk membeli cinderamata.

\subsection{Pemenuhan Fasilitas Rekreasi dan Sarana Wisata}

Pengembangan Gedung Merdeka sebagai destinasi perlu memperhatikan sarana rekreasi dan sarana wisata untuk kebutuhan wisatawan. Sebagaimana diketahui bahwa salah satu tujuan orang berwisata adalah untuk bersenang-senang, hiburan, dan rekreasi. Dengan demikian, sangat penting adanya berbagai macam sarana wisata yang bertujuan untuk menambah betah wisatawan mengunjungi Gedung Merdeka. Sarana wisata yang perlu ditambah dan diadakan seperti cafetaria, coffee shop, tempat duduk dan bersantai, ruang makan-minum untuk wisatawan. Dengan demikian, wisatawan selain dapat mengunjungi Museum KAA dan menelusuri Gedung Merdeka juga dapat makan, minum, dan bersantai di tempat yang telah disediakan.

Setelah sarana wisata ditambah, langkah selanjutnya yang harus sediakan untuk pemenuhan kebutuhan wisatawan ialah fasilitas rekreasi. Hal ini dapat dilakukan dengan menyajikan pertunjukan kesenian khas Bandung, misalnya dengan menampilkan kesenian dari pelajar-pelajar di Kota Bandung atau dari kelompok pecinta seni Sunda. Selain itu apabila telah dijalin kerja sama dengan pihak kedutaan negara-negara Asia Afrika, dapat juga dipentaskan kesenian dari negara-negara tersebut

Di samping itu, perlu juga ditampilkan film tentang sejarah KAA, suasana Kota Bandung saat dipersiapkan menyambut KAA, dan sejarah Museum KAA dalam bentuk tiga dimensi. Dalam memutar film tiga dimensi harus disediakan ruangan yang lebih nyaman, luas, dan menarik serta sesuai kebutuhan wisatawan, misalnya seperti ruangan audio visual di Museum Bank Indonesia, Museum Wayang di Jakarta, atau seperti Bioskop XXI. Dengan demikian, ada unsur entertainments di Gedung Merdeka.

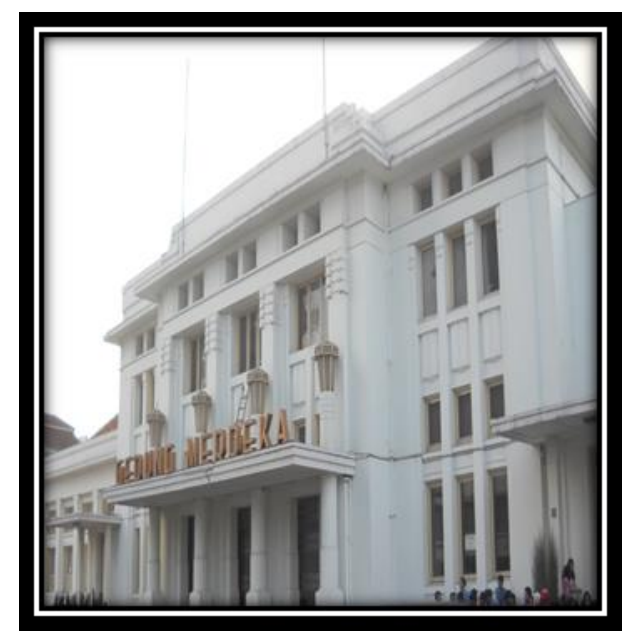

Gambar 6. Gedung Merdeka pada 2012 Sumber: Dokumentasi Pribadi (Foto diambil pada 10 Juli 2012)

Koleksi pameran tetap di museum KAA perlu ditambah lagi dengan benda yang berhubungan dengan konferensi 1955. Salah satu benda yang dapat dijadikan koleksi museum seperti mobil yang digunakan oleh Presiden Soekarno, 
Moh. Hatta, Ali Sastroamidjoja, maupun kendaraan yang dipakai oleh perdana menteri negara sponsor konferensi dan para pimpinan delegasi. Pihak pengelola museum harus dapat mencari keberadaan kendaraan tersebut untuk dipamerkan. Selain itu, busana yang dipakai oleh para kepala negara dan kepala delegasi dapat dijadikan koleksi museum. Busana tersebut akan mencerminkan kebudayaan dan ciri khas negaranya dan akan menjadi sebuah daya tarik apabila dipajangkan di museum.

Komplek Gedung Merdeka yang terdapat di Jalan Asia Afrika dan Jalan Braga merupakan sebuah tempat favorit untuk para pecinta fotografi. Dengan demikian kegiatan fotografi ini dapat dijadikan sebagai daya tarik wisata. Pihak pengelola Gedung Merdeka dapat memfasilitasi kegiatan fotografi dengan cara menyediakan lokasi atau ruangan yang cocok dan menarik untuk kegiatan ini. Setelah itu, wisatawan yang berkunjung dapat memanfaatkan fasilitas ini. Sebagai contoh kegiatan fotografi di lokasi bersejarah yaitu di kawasan Kota Tua Jakarta.

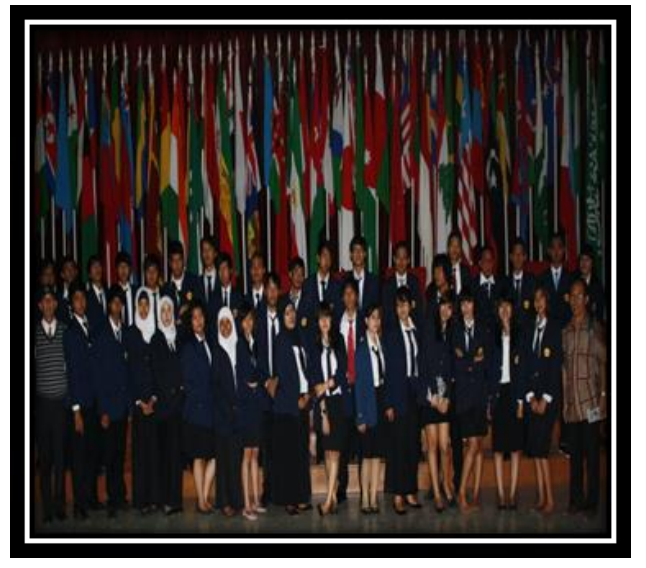

Gambar 7. Foto Grup Mahasiswa Ilmu Sejarah, Usaha Perjalanan Wisata, dan dosen Unpad di Main Hall Gedung Merdeka

Sumber: Dokumentasi Pribadi (Foto diambil Pada 13 September 2011)

Di samping itu, area parkir perlu diperluas agar dapat menampung kendaraan lebih banyak, karena wisatawan yang berkunjung ke Museum KAA tidak hanya dari kalangan pendidikan melainkan masyarakat umum juga. Wisatawan biasanya berkunjung secara rombongan dan memakai jasa angkutan bus pariwisata. Selain memanfaatkan tempat parkir yang ada di sebelah Gedung Merdeka juga dapat memanfaatkan Jalan Cikapundung Timur dan mencari alternatif lain.

\subsection{Optimalisasi Fungsi Gedung Merdeka}

Museum KAA merupakan sebuah museum yang memamerkan peninggalan, foto dan benda Konferensi Asia Afrika 1955. Museum ini berada di sayap kiri Gedung Merdeka. Selain melihat foto Konferensi Asia Afrika, wisatawan juga dapat menikmati fasilitas perpustakaan, ruang audio visual, ruang bundar, mushola, dan ruang souvenir. Akan tetapi, menurut penelitian penulis fungsi ruangan tersebut selama ini belum dimanfaatkan secara maksimal untuk menarik wisatawan yang berkunjung. Oleh sebab itu, perlu adanya optimalisasi fungsi fasilitas yang ada di Museum KAA untuk kepentingan wisatawan. Hal ini dapat dilakukan dengan cara pengemasan yang lebih menarik lagi maupun penyajian ruangan tersebut yang lebih modern atau sesuai perkembangan kebutuhan wisatawan serta melakukan perawatan yang maksimal. Fasilitas yang ada dan perlu optimalisasi fungsi seperti:

\section{a. Perpustakaan}

Perpustakaan yang ada sekarang ruangannya cukup kecil dan koleksinya pun perlu ditambah. Hal ini dapat diatasi dengan memanfaatkan gedung bekas perpustakaan daerah yang berada di belakang ruang utama (main hall) Gedung Merdeka. Gedung ini terdiri dari dua lantai dan bisa dimanfaatkan sebagai Gedung Perpustakaan KAA. Setelah itu, fasilitas dan koleksi perpustakaan harus ditingkatkan dan penataan ruangan yang artistik dan menarik.

b. Ruang Audio Visual 
Ruang audio visual merupakan ruangan tempat ditanyangkannya film-film dokumenter terkait Konferensi Asia Afrika. Konsep ruangan ini seperti ruang perkuliahan yang disediakan proyektor dan kursi yang berjejer. Selain itu, tidak semua pengunjung Museum KAA tertarik masuk ruangan ini karena pintu masuknya berada di koridor belakang ruangan pameran utama. Di Samping itu, kurang informasi mengenai adanya pemutaran film dokumenter yang dapat dilihat di ruangan audio visual. Supaya menarik wisatawan masuk ke ruang audio visual, konsep dekorasi ruangan tersebut harus lebih menarik dan modern. Ruang audio visual agar lebih menarik wisatawan yang berkunjung diusahakan seperti ruangan Bioskop. Di samping itu, film-film yang disajikan tidak hanya dalam bentuk dokumenter, tetapi dalam bentuk film tiga dimensi seperti yang ada pada Museum Wayang di Kota Tua Jakarta.

\section{c. Ruang Souvenir}

Ruang souvenir selama ini hanya menjual cinderamata yang berkaitan dengan Konferensi Asia Afrika. Cinderamata itu seperti pin, mug, gantungan kunci, kaos yang gambarnya bertema KAA. Hal ini sudah menarik untuk wisatawan membelinya, tetapi lokasi tempat penjualannya yang kecil dan berdekatan dengan toilet menjadi kurang strategis. Oleh sebab itu, ruangan souvenir juga harus diperhatikan dan ditempatkan di ruangan yang luas dan strategis serta penataan yang menarik dan membuat wisatawan ingin mendatanginya. Di samping itu, ragam cinderamata yang dijual dapat ditambah dengan kerajinan khas Bandung atau Jawa Barat. Dengan demikian wistawan yang berkunjung ke Gedung Merdeka akan mengetahui jenis kerajinan khas Kota Bandung dan Jawa Barat.

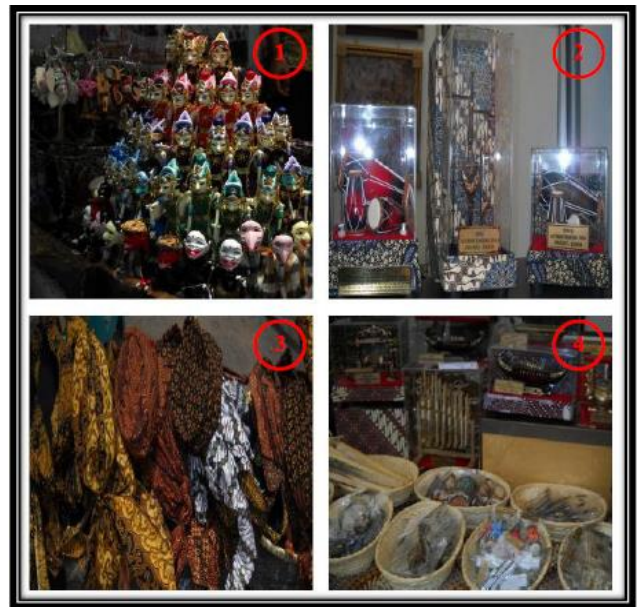

Gambar 8. Jenis Souvenir yang ditawarkan Penulis

Sumber: Dokumentasi Pribadi (Foto diambil pada 29 September 2012)

Setelah optimalisasi fungsi fasiltas yang ada di Museum KAA untuk kepentingan wisatawan, langkah selanjutnya yaitu optimalisasi fungsi ruangan dan fasilitas yang ada di komplek Gedung Merdeka. Ruangan VIP yang berada di sebelah ruang utama harus dapat dilihat dan dikunjungi wisatawan. Mengingat ruang ini memiliki nilai historis serta memiliki gaya yang khas serta jumlah ruangannya lebih dari satu buah. Apabila hal ini dijadikan daya tarik maka pengunjung akan merasa lebih mendapatkan pengetahuan dan unsur rekreasi.

Dengan cara melihat ruangan VIP, wisatawan akan mengetahui tokoh dunia mana saja yang pernah berada di ruangan tersebut. Di samping itu, wisatawan juga akan mendapatkan pengalaman berharga bahwa ia telah mengetahui dan melihat langsung ruangan dan kursi yang dipakai para tamu negara ketika istirahat saat konferensi Asia Afrika 1955. Dengan demikian, perlu adanya informasi yang jelas di setiap benda-benda yang ada di ruangan VIP dan komplek Gedung Merdeka.

Gedung Merdeka merupakan bangunan yang didirikan pada masa kolonial serta menjadi salah satu bangunan yang representatif untuk ukuran 
zamannya. Hal tersebut dapat dilihat dari gaya arsitektur gedung serta langit-langit di dalam ruangan. Jika wisatawan mengunjungi ruangan VIP, maka akan terlihat unsur kemegahan dan nilai estetis dari Gedung Merdeka. Langit-langit di ruangan VIP masih memperlihatkan gaya arsitekturnya.

Bukan hanya ruangan VIP yang dapat dilihat dan dinikmati oleh wisatawan, tetapi ruangan yang berada di lantai dua pun perlu ditawarkan ke wisatawan. Di ruangan tersebut masih terdapat lampu hias dan lantai yang diperkirakan berasal dari masa kolonial (Wawancara dengan Agus pada 26 September 2012). Setelah itu ruangan bawah tanah pun perlu adanya perawatan yang maksimal. Dengan perawatan dan penataan yang baik, ruangan tersebut dapat diatawarkan ke wisatawan untuk dikunjungi.

Dalam optimalisasi fungsi Gedung Merdeka sebagai objek wisata perlu diperhatikan juga beberapa aspek berikut:

a. Penampilan pintu masuk, petunjuk arah dan denah lokasi, serta bagian informasi atau customer service.

b. Sirkulasi kunjungan wisatawan dalam mengunjungi area pameran dan tata letak ruangan di Gedung Merdeka.

c. Daya dukung bahan audio visual, pengeras suara, dan pramuwisata yang menyajikan informasi yang menarik dan tidak membosankan (Yoeti, 2006: 17).

\subsection{Kerja Sama}

Dalam pengembangan Gedung Merdeka sebagai objek wisata budaya di Kota Bandung dibutuhkan juga dukungan dari berbagai kalangaan. Oleh sebab itu, pengelola Gedung Merdeka dan Museum KAA dituntut untuk dapat mengadakan kerja sama dengan berbagai pihak. Kerja sama tersebut dapat dilakukan dengan pemerintah kota, pihak swasta, dan masyarakat Kota Bandung. Kerja sama dengan pihak swasta dapat dilakukan dengan pengusaha tour and travel, organisasi kepariwisataan, hotel, restoran, pengusaha ekonomi kreatif di Kota Bandung, perguruan tinggi, penggiat seni dan hobi, bank, radio, serta media cetak dan elektronik. Hal ini dimaksudkan agar mendapat dukungan dan bantuan dalam penyelengaraan kegitan yang direncanakan, serta untuk pemasaran wisata. Di samping itu, pihak-pihak yang telah bekerja sama dapat meramaikan dan menghidupkan Gedung Merdeka dengan berbagai macam kegiatan dan hiburan serta dapat mengisi stand penjulan souvenir. Pelaksanaan kerja sama dapat dilakukan melalui perjanjian yang dapat memberikan keuntungan bagi kedua belah pihak.

\subsection{Promosi}

Salah satu kegiatan untuk mengenalkan sebuah objek wisata agar dikunjungi wisatawan adalah dengan melakukan promosi. Dengan melakukan kegiatan promosi yang dilakukan secara menarik dan sampai kepada calon wisatawan, diharapkan dapat meningkatkan arus kunjungan. Promosi pariwisata bertujuan untuk memberitahukan segala sesuatu yang berhubungan dengan kepariwisataan, membujuk calon wisatan untuk berkunjung ke Gedung Merdeka. Promosi ini dapat dilakukan dengan cara pemasangan iklan di berbagai media cetak dan elektronik, berbagai promosi penjualan, hubungan masyarakat, penyelenggaraan paket wisata pengenalan (Wahab, 1992: 252). Promosi dapat dilakukan dengan mendatangi secara langsung ke sekolah-sekolah. Di samping itu, bekerja sama dengan biro perjalanan wisata sehingga Gedung Merdeka dimasukan dalam paket wisata. Promosi dapat juga dilakukan dengan mengikuti kegiatan dan pameran pariwisata, lewat radio, televisi, dan internet. Untuk promosi dengan media booklet dan brosur harus tetap dilakukan oleh pihak pengelola. Mengingat di Kota Bandung banyak terdapat tempat strategis yang menjadi pintu masuk wisatawan, maka promosi dengan menggunakan papan reklame harus 
diusahakan. Dengan adanya papan reklame di lokasi strategis diharapkan dapat memudahkan orang mengetahui adanya Gedung Merdeka dan Museum Konferensi Asia Afrika sebagai objek wisata di Kota Bandung.

\section{PENUTUP}

Gedung Merdeka adalah salah satu benda cagar budaya yang dapat dijadikan sebagai objek wisata di Kota Bandung. Daya tarik wisata yang ditawarkan yaitu adanya Museum Konferensi Asia Afrika (KAA) dan nilai historis gedung tersebut yang berhubungan dengan penyelenggaraan KAA 1955. Di dalam Museum KAA dipamerkan benda dan foto yang berhubungan dengan peristiwa konferensi dan keadaan fisik gedung tersebut yang masih kokoh. Komplek Gedung Merdeka sebagai bukti sejarah KAA 1955 belum secara optimal dimanfaatkan sebagai daya tarik wisata. Masih adanya ruangan yang belum dapat dikunjungi oleh wisatawan, koleksi Museum KAA yang kurang variatif, minimnya sarana wisata yang tersedia, dan promosi yang belum maksimal dilakukan sehingga membuat Museum KAA belum menjadi objek wisata unggulan.

$\begin{array}{lccc}\text { Gedung } & \text { Merdeka dan Museum } \\ \text { KAA sangat } & \text { penting untuk terus } \\ \text { dikembangkan } & \text { dan } & \text { dilestarikan. }\end{array}$ Pengembangan tersebut dapat dilakukan melalui pariwisata. Pariwisata merupakan pilihan yang sesuai untuk mendukung usaha pelestarian serta penyebarluasan semangat KAA. Oleh sebab itu, perlu optimalisasi fungsi gedung tersebut sebagai daya tarik wisata, pemenuhan sarana wisata, menambah koleksi Museum KAA, pemutaran film tiga dimensi, dan pertunjukan kesenian yang diharapkan dapat membuat wisatawan lebih tertarik untuk berkunjung. Guna mewujudkan semua itu, diperlukan sebuah manajemen organisasi yang bertanggung jawab penuh atas komplek gedung tersebut sebagai objek wisata.

\section{UCAPAN TERIMA KASIH}

Ucapan terima kasih penulis sampaikan kepada Asep Bahrimansyah Gunawan, M.Hum., beserta staf Museum Konferensi Asia Afrika dan staf Badan Pengelola Gedung Merdeka yang telah berkenan menjadi narasumber dan membantu proses pengumpulan dokumen penelitian.

\section{DAFTAR SUMBER}

\section{Laporan, Skripsi, dan Disertasi}

BPS Kota Bandung. 2011.

Kota Bandung dalam Angka Tahun 2011.

Departemen Luar Negeri RI. Direktorat

Diplomasi Publik; Ditjen Informasi dan Diplomasi Publik. 2011.

Revitalisasi Museum Konferensi Asia Afrika, Bandung; Kegiatan TahunJamak 2008-2012.

Hardjasaputra, A. Sobana. 2002.

"Perubahan Sosial di Bandung 18101906". Disertasi. Depok: Program Pascasarjana Fakultas Sastra Universitas Indonesia.

Rakhman, Krishna Taufiq, 2011. "Dinamika Pemasaran Objek wisata Cipanas Kabupaten Garut (19862009)". Skripsi. Jatinangor: Jurusan Ilmu Sejarah Fakultas Sastra Universitas Padjadjaran.

\section{Buku}

Abdulgani, Roeslan. 2011.

The Bandung Connection; Konferensi Asia Afrika di Bandung Tahun 1955. MKAA, Dirjen Diplik Kemenlu RI.

Buitenweg, Hein. 1976.

Bandoeng. Wassenaar: Servire B.V.

Ekadjati, Edi S. 1981.

Sejarah Kota Bandung Periode Revolusi Kemerdekaan (1945-1950).

Bandung: Pemerintah Kotamadya Daerah Tingkat II Bandung dan Universitas Padjadjaran.

Edi S. 2004.

Panduan Museum Konferensi Asia Afrika. Bandung: Museum Konferensi Asia Afrika.

Herlina, Nina. 2008. 
Metode Sejarah. Bandung: Satya Historika.

Hutagalung, Ridwan dan Taufanny Nugraha. 2008.

Braga; Jantung Parijs Van Java. Depok: Ka Bandung.

MKAA, Dirjen Diplik Kemenlu RI. 2011. Sejarah Konferensi Asia Afrika.

Moleong, Lexy J. 2012.

Metodologi Penelitian Kualitatif; Edisi Revisi. Bandung: Remaja Rosdakarya.

Wahab, Salah. 1992.

Pemasaran Pariwisata (terjemahan). Jakarta: Pradnya Paramita.

Yoeti, Oka A. 1996.

Pengantar Ilmu Pariwisata. Bandung: Angkasa

Oka A. 1996.

Pemasaran Pariwisata. Bandung: Angkasa

Oka A. 2006.

Pariwisata Budaya: Masalah dan solusinya. Jakarta: Pradnya Paramita.

\section{Sumber Lisan}

Agus Bunyamin (44 Tahun), 2012.

PNS Badan Pengelola Gedung Merdeka. Wawancara, Bandung, 26 September 2012. 